\title{
Automatizáltan mérhető biomarkerek az akut myocardialis infarctus diagnosztikájában
}

\author{
Kovács Ferenc dr. ${ }^{1}$ - Kocsis Ibolya dr. ${ }^{2}$ - Varga Marina $d r .{ }^{3}$ \\ Sárváry Enikő dr. ${ }^{3}$ - Bicsák György dr. ${ }^{4}$ \\ ${ }^{1}$ Kanizsai Dorottya Kórház, Központi Laboratórium, Nagykanizsa \\ Semmelweis Egyetem, Általános Orvostudományi Kar, ${ }^{2}$ Laboratóriumi Medicina Intézet, \\ ${ }^{3}$ Transzplantációs és Sebészeti Klinika, Budapest \\ ${ }^{4}$ Kanizsai Dorottya Kórház, Sürgősségi Osztály, Nagykanizsa
}

\begin{abstract}
Bevezetés: A szív biomarkerei kiemelkedő szerepet kaptak az akut myocardialis infarctus diagnosztikájában. Célkitüzés: A szerzők automatizáltan mérhető szívbiomarkerek diagnosztikai hatékonyságát vizsgálták. Módszer: Mieloperoxidázt, nagy érzékenységű C-reaktív fehérjét, mioglobint, szívtípusú zsírsavkötő fehérjét, kreatinkinázt, kreatinkinázMB-t, nagy érzékenységü troponin-I-t és -T-t mértek. Eredmények: Akut myocardialis infarctusban a leghatékonyabbnak (görbe alatti terület: 0,86;95\%-os megbízhatósági tartomány: 0,77-0,95; p<0,001) a nagy érzékenységú troponin-I bizonyult. A kritikus értéknél $(0,35 \mathrm{ng} / \mathrm{mL})$ az érzékenység $81 \%$, a fajlagosság $74 \%$ volt. A nagy érzékenységű troponin-T, -I, a mellkasi fájdalom és az elektrokardiogram együttes értékelése különítette el legjobban az akut myocardialis infarctust az egyéb kórképektől (korrekt besorolás: 62,5\% és 98,9\%). Következtetések: Amíg nem áll rendelkezésre megfelelő érzékenységű és fajlagosságú szívbiomarker, addig nincs jobb módszer az akut myocardialis infarctus gyanúja esetén, mint 3-6 óra múlva újra elvégezni az elektrokardiogram- és biomarker-vizsgálatot. Orv. Hetil., 2015, 156(24), 964-971.
\end{abstract}

Kulcsszavak: akut myocardialis infarctus, szívbiomarkerek

\section{Automated measurement of biomarkers for the diagnosis of acute myocardial infarction}

Introduction: Cardiac biomarkers have a prominent role in the diagnosis of acute myocardial infarction. Aim: The aim of the authors was to study the diagnostic effectiveness of automated measurement of cardiac biomarkers. Method: Myeloperoxidase, high-sensitivity C-reactive protein, myoglobin, heart-type fatty acid binding protein, creatine kinase, creatine kinase MB, high-sensitivity troponin I and T were measured. Results: The high-sensitivity troponin I was the most effective (area under curve: 0.86 ; 95\% confidence interval: $0.77-0.95 ; \mathrm{p}<0.001$ ) for the diagnosis of acute myocardial infarction. Considering a critical value of $0.35 \mathrm{ng} / \mathrm{mL}$, its sensitivity and specificity were $81 \%$, and $74 \%$, respectively. Combined evaluation of the high-sensitivity troponin $\mathrm{T}$ and $\mathrm{I}$, chest pain, and the electrocardiogram gave the best results for separation of acute myocardial infarction from other diseases (correct classification in $62.5 \%$ and $98.9 \%$ of patients, respectively). Conclusions: Until a more sensitive and specific cardiac biomarker becomes available, the best method for the diagnosis of acute myocardial infarction is to evaluate electrocardiogram and biomarker concentration and to repeat them after 3-6 hours.

Keywords: acute myocardial infarction, cardiac biomarkers

Kovács, F., Kocsis, I., Varga, M., Sárváry, E., Bicsák, Gy. [Automated measurement of biomarkers for the diagnosis of acute myocardial infarction]. Orv. Hetil., 2015, 156(24), 964-971.

(Beérkezett: 2015. február 13.; elfogadva: 2015. március 19.) 


\section{Rövidítések}

AMI = akut myocardialis infarctus; CI = 95\%-os megbízhatósági tartomány; $\mathrm{CK}=$ kreatinkináz; $\mathrm{CKMB}=$ kreatinkináz-MBtípusú izoenzim; COPD = krónikus obstruktív tüdőbetegség; HFABP = szívtípusú zsírsavkötő fehérje; hsCRP = nagy érzékenységű C-reaktív fehérje; hsTnI = nagy érzékenységű tropinin-I; hsTnT = nagy érzékenységü troponin-T; $\mathrm{MPO}=$ mieloperoxidáz; $\mathrm{MVT}=$ mélyvénás thrombosis $; \mathrm{MYO}=$ mioglobin; ROC = hatásfelmérő jelleggörbe; $s n$ = érzékenység; $s p=$ fajlagosság; TIA = átmeneti ischaemiás roham

Az ezredforduló óta csökkent a szív- és érrendszeri betegségekben meghaltak száma, de még mindig a vezető halálok Magyarországon. Ezen belül 14,5\%-ra volt tehetô az akut myocardialis infarctusban elhunytak száma 2013-ban [1]. Az akut myocardialis infarctus (AMI) harmadik egységes definíciója szerinti egyes típusban (klaszszikus AMI) az arteria coronariában lévő atheroscleroticus plakk repedése, eróziója thromboticus események láncolatát idézi elő, ami elzárja az eret, ezért megszakad a myocardium vér- és oxigénellátása infarktust idézve elő. A következményes necrosis szívelégtelenséget, myocardiumrepedést vagy arrhythmiát okoz. A myocardialis ischaemia korai kezelése (megelőzendő a necrosist) javítja az életkilátásokat. Ezért nagyon fontos, hogy időben felállítsuk a helyes diagnózist. Ebben kiemelkedő szerepet kaptak a szív biomarkerei, amelyek javítják a diagnosztikus hatékonyságot, mivel a kezelések nem kockázatmentesek. Ezenkívül prognosztikus információval is szolgálnak a betegségrőll $[2,3]$. A sürgősségi osztályra került betegeknél mértünk neutrophilgranulocyta-aktivációt (MPO), gyulladást (hsCRP), praenecrosist (MYO, HFABP) és necrosist (CK, CKMB, hsTnI, hsTnT) jelző szívbiomarkereket. Meghatároztuk ezen anyagok koncentrációját, aktivitását szív- és nem szíveredetü betegségekben is. Értékeltük a biomarkerek diagnosztikai hatékonyságát AMI-ban.

\section{Módszer}

A sürgősségi osztályon megjelent betegek közül azokat választottuk be a kísérletbe, akiknek legalább egyik, a laboratóriumban rutinszerúen mért szívbiomarker- $(\mathrm{CK}$, CKMB, MYO, hsTnI) szintje kóros volt és/vagy mellkasi fájdalom tünettel jelentkeztek. A kiválasztás utólagosan történt a laboratóriumi eredmények és az anamnézis alapján. Kisebb számban véletlenszerüen is beválogattunk betegeket. Ezután meghatároztuk a HFABP-, a hsTnT-, az MPO- és a hsCRP-szinteket is a -20 Celsiusfokon tartott maradék szérummintákból, valamint rögzítettük a diagnózisokat a kórtörténetekből. A lipaemiás, hyperbilirubinaemiás vagy hemolizált mintákat kizártuk. A CK-, CKMB- és hsCRP-méréseket a Diagnosticum Zrt. (Magyarország) reagenseivel, a HFABP-vizsgálatot Randox (Észak-Írország) reagenssel ADVIA 2400-as automatán (Siemens, Németország) végeztük el. A MYO- és hsTnI-szinteket Immulite 2000 (Siemens, Németország), a hsTnT-t Cobas e4ll (Roche, Svájc), az MPO-t Architect il000SR (Abbott, Egyesült Államok) automatán mértük a gyártók tesztjeivel. Az analitok gyártók által megadott referenciatartományát, illetve kritikus értékét használtuk, amit az 1. táblázat mutat. A szíveredet valószínüsítésére az irodalomban leírt képleteket is felhasználtuk: $(\mathrm{CKMB} / \mathrm{CK}) \times 100, \mathrm{MYO} / \mathrm{HFABP}$.

1. táblázat | Referenciatartományok és kritikus értékek

\begin{tabular}{ll}
\hline Vizsgálat & \\
\hline $\mathrm{LDH}$ & $240-480 \mathrm{U} / \mathrm{L}$ \\
$\mathrm{CK}$ & $20-200 \mathrm{U} / \mathrm{L}$ \\
$\mathrm{CKMB}$ & $<25 \mathrm{U} / \mathrm{L}$ \\
$\mathrm{MYO}$ & $<70 \mathrm{ng} / \mathrm{mL}$ \\
$\mathrm{HFABP}$ & $<6,32 \mathrm{ng} / \mathrm{mL}$ \\
TnI & $<0,35 \mathrm{ng} / \mathrm{mL}$ \\
TnT & $<0,1 \mathrm{ng} / \mathrm{mL}$ \\
$\mathrm{MPO}$ & $<670 \mathrm{pmol} / \mathrm{L}$ \\
$\mathrm{CRP}$ & $<10 \mathrm{mg} / \mathrm{L}$ \\
\hline
\end{tabular}

\section{Statisztikai elemzés}

Az adatok feldolgozásához az SPSS 13.0 for Windows (SPSS Inc.) programot használtuk. Az adatok eloszlását Shapiro-Wilk-teszttel vizsgáltuk. ROC-analízist alkalmaztunk a markerek diagnosztikai hatékonyságának (a görbe alatti terület értéke mutatja) felmérésére szív- és nem szíveredetű kórképekben, illetve AMI-ban. Ha az érték 0,9-1,0 közötti, a hatékonyság kiváló, 0,8-0,9 között jó, 0,7-0,8 között elfogadható, 0,6-0,7 között gyenge és 0,6 alatt elfogadhatatlan volt. Az optimális kritikus értékek megállapításához a $\sqrt{(1-s n)^{2}+(1-s p)^{2}}$ képlettel meghatároztuk a ROC-görbe bal felső sarkához $(0$, 1) legközelebb eső mérési pontot. A MYO-HFABP és hsTnI-hsTnT egymáshoz való viszonyát Spearman-korrelációval vizsgáltuk. Annak megítélésére, hogy a változók értékei különböznek-e a szív- és nem szíveredetü kórképekben, illetve AMI-ban, Kruskal-Wallis-próbát alkalmaztunk. A próba eredménye alapján bináris logisztikus regresszió analízist végeztünk. Az analizis feltételei voltak: 1. Egyenleten kívüli változók $(\mathrm{p}<0,05)$. 2. Omnibusz teszt $(\mathrm{p}<0,05)$. 3. Modell-összegzés (Nagelkerke R-négyzet $>0,7)$. 4. Hosmer-Lemeshow-teszt $(p>0,05)$. 5. Klasszifikációs táblázat (teljes százalék a kezdő tömbben < teljes százalék az l-es tömbben). 6. Változók az egyenletben Wald-kritérium $(\mathrm{p}<0,05)$. Wilcoxon-próbát alkalmaztunk a felvételkori és a később (6 órán belül) elvégzett hsTn-mérés eredményeinek összehasonlítására.

\section{Eredmények}

Összesen 205 beteget vizsgáltunk. 100 nő (életkor: 1890 év, medián: 75 év) és 105 férfi (életkor: 23-93 év, 
medián: 62 év) alkotta a betegcsoportot. Mellkasi fájdalom tünettel és/vagy kóros szívbiomarkerszinttel rendelkező betegek száma 188 fó volt. 35 betegnél készült második szívbiomarker-mérés is. A betegek tünet és diagnózis szerinti megoszlását mutatja a 2. táblázat. A leggyakoribb tünet a mellkasi fájdalom, míg a leggyakoribb diagnózis az egyéb mellkasi fájdalom volt. Az AMI-k 81\%-ánál mellkasi fájdalom, 19\%-ánál eszméletvesztés volt a tünet. Egyik változó értékei sem mutattak normális eloszlást $(\mathrm{p}<0,001)$. A szív- és nem szíveredetű kórképeket vizsgálva az analitok és képletek ROC-görbe alatti terület értéke minden esetben 0,7 alatt volt. Ezt a határt a $(\mathrm{CKMB} / \mathrm{CK}) \times 100$ képlettel számolt értékek görbe alatti területe $(0,65, \mathrm{CI}: 0,54-0,77, \mathrm{p}=0,014)$ közelítette meg legjobban. AMI-ban a diagnosztikai hatékonyság elfogadható volt a MYO $(0,71, \mathrm{CI}$ : $0,57-$

2. táblázat | Tünetek és diagnózisok (zárójelben a betegszám)

\begin{tabular}{|c|c|}
\hline Beszédzavar (1) & Apoplexia cerebri (1) \\
\hline $\begin{array}{l}\text { Eszméletvesztés } \\
(35)\end{array}$ & $\begin{array}{l}\text { AMI (3), delirium tremens (1), epilepszia } \\
\text { exsiccosis ( } 1) \text {, hyperglikaemiás ketoacidos } \\
\text { hypoglikaemia }(2) \text {, ictus caloris }(1) \text {, sokk } \\
\text { collapsus }(2) \text {, pancreatitis acuta }(2) \text {, fibrill } \\
\text { auricularis }(4) \text {, rhabdomyolysis }(3) \text {, apopl } \\
\text { cerebri }(3) \text {, arrhythmia cardiaca }(2) \text {, embc } \\
\text { pulmonum (2), infarctus cerebri (1) }\end{array}$ \\
\hline Fejfájás (2) & Cephalalgia (1), hypertonia (1) \\
\hline Fulladás (30) & $\begin{array}{l}\text { Bronchitis acuta }(5), \text { COPD }(1) \text {, } \\
\text { hydrothorax }(2) \text {, bronchitis chronica }(1) \text {, } \\
\text { decompensatio cardiaca }(9) \text {, } \\
\text { fibrillatio auricularis }(3) \text {, pneumonia }(4) \text {, } \\
\text { neoplasma pulmonum malignum }(2), \\
\text { oedema pulmonum }(3)\end{array}$ \\
\hline
\end{tabular}

Gyengeség (20) Infarctus cerebri (1), cholecystitis (1), exsiccosis (2), anxietas (1), TIA (15)

Hányás (3) Gastritis acuta (1), subileus (2)

Hasfájás (5) Exsiccosis (1), hyperaciditas (1), pancreatitis acuta (1), szeptikus sokk (2)

Lábduzzadás (5) MVT (2), decompensatio cardiaca (3)

Láz (6)

Mellkasi fájdalom AMI (13), angina pectoris (5), áramütés (1) (77)

Szapora szívverés Fibrillatio auricularis (4)

(4)

Szédülés (11)

Infarctus cerebri (1), exsiccosis (1), hyperglykaemia (2), hypertonia (2), hypoglykaemia (1), collapsus (1), insufficientia renalis chronica (2), TIA (1)

Szívdobogás (3) Arrhythmia cardiaca (3)

Zavartság (3) Delirium tremens (1), exsiccosis (1), suicidum (1)
$0,85, \mathrm{p}=0,006), \mathrm{CKMB}(0,77, \mathrm{CI}: 0,6-0,93, \mathrm{p}<0,001)$ és a $(\mathrm{CKMB} / \mathrm{CK}) \times 100(0,77, \mathrm{CI}: 0,62-0,92, \mathrm{p}<0,001)$ képlet esetében. Ugyanakkor a $\operatorname{HFABP}(0,81, \mathrm{CI}: 0,7 \mathrm{l}-$ $0,91, \mathrm{p}<0,001)$, hsTnI $(0,86$, CI: $0,77-0,95, \mathrm{p}<0,001)$ és hsTnT $(0,85, \mathrm{CI}: 0,76-0,93, \mathrm{p}=0,001)$ esetében jó volt ez a jellemző. Leghatékonyabbnak a hsTnI bizonyult. A kritikus értéknél $(0,35 \mathrm{ng} / \mathrm{mL})$ az érzékenység $81 \%$, a fajlagosság $74 \%$, míg a hsTnT (kritikus érték: 0,1 $\mathrm{ng} / \mathrm{mL}$ ) és HFABP (kritikus érték: $6,32 \mathrm{ng} / \mathrm{mL}$ ) esetében $44 \%, 91 \%$ és $100 \%, 40 \%$ volt (1. ábra). Az optimális kritikus értékek: hsTnI $(0,29 \mathrm{ng} / \mathrm{mL}$, érzékenység $88 \%$, fajlagosság $74 \%)$, hsTnT $(0,025 \mathrm{ng} / \mathrm{mL}$, érzékenység $88 \%$, fajlagosság $72 \%)$, HFABP $(37,4 \mathrm{ng} / \mathrm{mL}$, érzékenység $69 \%$, fajlagosság $87 \%$ ). A MYO-HFABP (173 eset [84\%], illetve hsTnI-hsTnT (146 eset [71\%]) értékek nagyrészt egy irányba mozogtak. Vagyis kóros MYOkoncentrációhoz kóros, míg normálishoz normális HFABP-koncentráció társult, ahogy a hsTnI és hsTnT vonatkozásában is. Ezt erősítette meg a Spearman-korreláció (MYO-HFABP: $\mathrm{r}=0,88, \mathrm{p}=0,0 \mathrm{l}$; hsTnI-hsTnT: $\mathrm{r}=0,63, \mathrm{p}=0,01)$. A kritikus értékek feletti koncentrációkat előidéző kórképeket mutatja a 3. táblázat. Látható, hogy a MYO-HFABP esetében sokféle és szinte ugyanazok a betegségek fordultak elö, míg a hsTnI-hsTnT vonatkozásában a hsTnI szintje kétszer annyi fajta kórképben emelkedett meg. Szív- és nem szíveredetü betegségekben szignifikánsan különböztek egymástól az MPO $(\mathrm{p}=0,049)$ és a $(\mathrm{CKMB} / \mathrm{CK}) \times 100(\mathrm{p}=0,004)$ képlettel számolt értékek. AMI-ban pedig a CK $(\mathrm{p}=0,009)$, CKMB $(\mathrm{p}<0,001),(\mathrm{CKMB} / \mathrm{CK}) \times 100(\mathrm{p}<0,001)$, MYO ( $\mathrm{p}<0,006)$, HFABP $(\mathrm{p}<0,001)$, MYO/HFABP $(\mathrm{p}<0,001)$, hsTnI $(\mathrm{p}<0,001)$, hsTnT $(\mathrm{p}<0,001)$ eredmények. A bináris logisztikus regresszió során a hsTnT és a hsTnI különítették el legjobban az AMI-t az egyéb kórképektól: 1. Egyenleten kívüli változók: hsTnT $(\mathrm{p}<0,001)$, hsTnI $(\mathrm{p}<0,001)$. 2. Omnibusz teszt $(\mathrm{p}<0,001)$. 3. Modell-összegzés (Nagelkerke R-négyzet $=0,29) .4$. Hosmer-Lemeshow-teszt $(\mathrm{p}=0,084) .5$. Klasszifikációs táblázat [teljes százalék a kezdő tömbben $(92,2 \%)<$ teljes százalék 1-es tömbben $(93,7 \%)]$. 6. Vál-

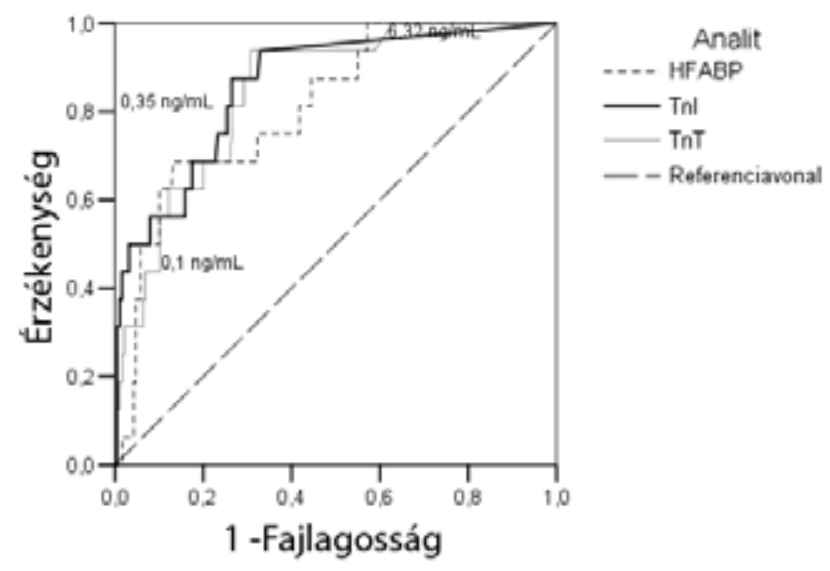

1. ábra |A diagnosztikailag leghatékonyabb analitok ROC-görbéje 
3. táblázat

Az emelkedett analitértékekhez tartozó diagnózisok

(kiemelve az eltérő diagnózisok a MYO-HFABP és TnI-TnT vonatkozásában)

\begin{tabular}{|c|c|}
\hline Analit & Diagnózis \\
\hline MYO & $\begin{array}{l}\text { AMI, anxietas, apoplexia cerebri, áramütés, arrhythmia } \\
\text { cardiaca, bronchitis acuta, bronchitis chronica, } \\
\text { cholecystitis, collapsus, COPD, cystitis acuta, } \\
\text { decompensatio cardiaca, delirium tremens, egyéb mellkasi } \\
\text { fájdalom, embolia pulmonum, epilepszia, exsiccosis, } \\
\text { fibrillatio auricularis, gastritis acuta, hydrothorax, } \\
\text { hyperglykaemia, hyperglykaemiás ketoacidosis, } \\
\text { hypertonia, hypoglykaemia, infarctus cerebri, } \\
\text { insufficientia renalis chronica, ischaemia myocardii, MVT, } \\
\text { myalgia, neoplasma pulmonum malignum, oedema } \\
\text { pulmonum, oesophagusreflux, pancreatitis acuta, } \\
\text { pneumonia, rhabdomyolysis, szeptikus sokk, sokk, } \\
\text { subileus, suicidum, TIA }\end{array}$ \\
\hline HFABP & $\begin{array}{l}\text { AMI, angina pectoris, anxietas, apoplexia cerebri, } \\
\text { arrhythmia cardiaca, bronchitis acuta, bronchitis chronica, } \\
\text { cholecystitis, collapsus, COPD, cystitis acuta, } \\
\text { decompensatio cardiaca, delirium tremens, egyéb mellkasi } \\
\text { fájdalom, embolia pulmonum, epilepszia, exsiccosis, } \\
\text { fibrillatio auricularis, gastritis acuta, hydrothorax, } \\
\text { hyperglykaemia, hyperglykaemiás ketoacidosis, } \\
\text { hypertonia, hypoglykaemia, infarctus cerebri, } \\
\text { insufficientia, renalis chronica, ischaemia myocardii, } \\
\text { MVT, myalgia, neoplasma pulmonum malignum, oedema } \\
\text { pulmonum, pancreatitis acuta, pneumonia, } \\
\text { rhabdomyolysis, szeptikus sokk, sokk, subileus, suicidum, } \\
\text { TIA }\end{array}$ \\
\hline TnI & $\begin{array}{l}\text { AMI, angina pectoris, apoplexia cerebri, bronchitis acuta, } \\
\text { cholecystitis, collapsus, decompensatio cardiaca, embolia } \\
\text { pulmonum, exsiccosis, fibrillatio auricularis, insufficientia } \\
\text { renalis chronica, oedema pulmonum, pancreatitis acuta, } \\
\text { pneumonia, rhabdomyolysis, szeptikus sokk, sokk, TIA }\end{array}$ \\
\hline $\operatorname{TnT}$ & $\begin{array}{l}\text { AMI, angina pectoris, collapsus, decompensatio cardiaca, } \\
\text { exsiccosis, insufficientia renalis chronica, szeptikus sokk, } \\
\text { subileus, TIA }\end{array}$ \\
\hline
\end{tabular}

tozók az egyenletben Wald-kritérium: hsTnI ( $\mathrm{p}=0,007)$, hsTnT (p = 0,001). AMI-ban 31,3\%, nem AMI-ban $98,9 \%$ volt a korrekt besorolás. Ez 62,5\%-ra és $98,9 \%$-ra változott, ha bevettük a statisztikai tesztbe a mellkasi fáj-

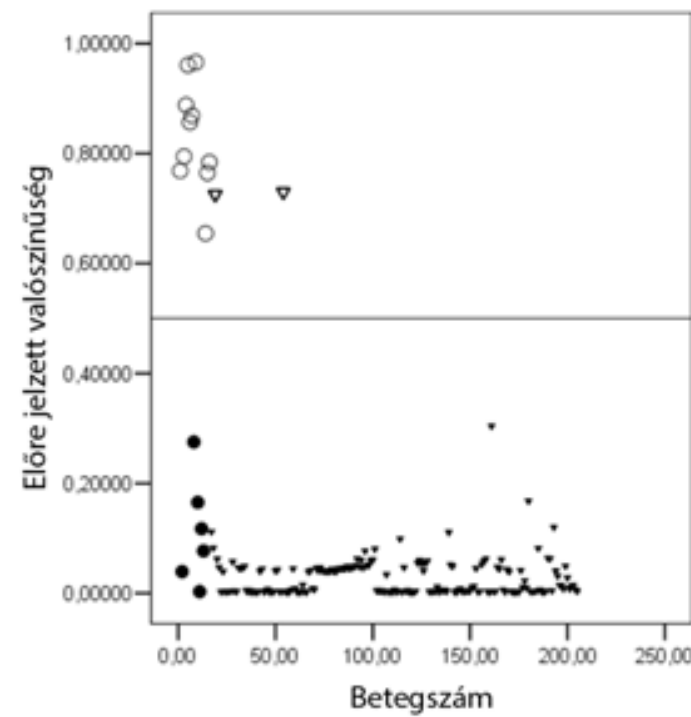

2. ábra

$$
\begin{aligned}
& \text { A betegek kórok szerinti besorolása a hsTnT-, hsTnI-értékek, } \\
& \text { a mellkasi fájdalom, valamint az EKG szerint } \\
& \text { felső téglalap: AMI, alsó téglalap: nem AMI; A = álnegatív bete- } \\
& \text { gek, a = valódi AMI, B = igazoltan nem AMI; b = álpozitív be- } \\
& \text { tegek }
\end{aligned}
$$

dalom tünetet és az EKG-görbe eredményét (1. Egyenleten kívüli változók: hsTnT $(\mathrm{p}<0,001)$, hsTnI $(\mathrm{p}<0,001)$, mellkasi fájdalom $(\mathrm{p}=0,001)$, EKG $(p<0,001) .2$. Omnibusz teszt $(p<0,001)$. 3. Modellösszegzés (Nagelkerke R-négyzet $=0,62)$. 4. HosmerLemeshow-teszt $(\mathrm{p}=0,055)$. 5 . Klasszifikációs táblázat [teljes százalék a kezdő tömbben $(92,2 \%)<$ teljes százalék az l-es tömbben $(96,1 \%)]$. 6. Változók az egyenletben Wald-kritérium: hsTnI $(\mathrm{p}=0,004), \operatorname{hsTnT}(\mathrm{p}=$ $0,009)$, mellkasi fájdalom $(p=0,021), E K G(p=0,001)$ (2. ábra). Az AMI-s betegeket vizsgálva minden esetben a kritikus érték feletti volt a HFABP-koncentráció a felvételkor. Ehhez társult valamelyik necrosist jelző bio-

\begin{tabular}{|c|c|c|c|c|c|c|c|c|c|}
\hline \multirow[t]{2}{*}{ Eset } & \multirow[t]{2}{*}{ Tünet } & \multirow[t]{2}{*}{ Kórkép } & \multicolumn{7}{|c|}{ Biomarkerszint } \\
\hline & & & $\begin{array}{l}\mathrm{LDH} \\
(\mathrm{U} / \mathrm{L})\end{array}$ & $\begin{array}{l}\mathrm{CK} \\
(\mathrm{U} / \mathrm{L})\end{array}$ & $\begin{array}{l}\text { CKMB } \\
(\mathrm{U} / \mathrm{L})\end{array}$ & $\begin{array}{l}\text { MYO } \\
(\mathrm{ng} / \mathrm{mL})\end{array}$ & $\begin{array}{l}\text { HFABP } \\
(\mathrm{ng} / \mathrm{mL})\end{array}$ & $\begin{array}{l}\text { hsTnI } \\
(\mathrm{ng} / \mathrm{mL})\end{array}$ & $\begin{array}{l}\text { hsTnT } \\
(\mathrm{ng} / \mathrm{mL})\end{array}$ \\
\hline 1. & Hasfájás & Szeptikus sokk & 825 & 210 & 57 & $>1000$ & 174,84 & 20 & 0,378 \\
\hline 2. & Láz & Exsiccosis & 583 & 60 & 5 & 98 & 38,17 & 14,1 & 0,305 \\
\hline 3. & Fulladás & Oedema pulmonum & 539 & 584 & 257 & $>1000$ & 1363 & 115 & 0,003 \\
\hline 4. & Fulladás & $\begin{array}{l}\text { Decompensatio } \\
\text { cardiaca }\end{array}$ & 948 & 8043 & 178 & $>1000$ & 298,56 & 7,41 & 0,386 \\
\hline 5. & Gyengeség & TIA & 542 & 340 & 33 & 157 & 36,71 & 6,65 & 0,390 \\
\hline 6. & Szédülés & $\begin{array}{l}\text { Insufficientia renalis } \\
\text { chronica }\end{array}$ & 404 & 614 & 33 & 715 & 109,25 & 2,28 & 0,113 \\
\hline 7. & Mellkasi fájdalom & Angina pectoris & 306 & 114 & 13 & 32 & 5,3 & 1,45 & 0,112 \\
\hline
\end{tabular}
marker-koncentráció emelkedése, kivéve 3 esetet, ahol kettőben csak az EKG-görbe volt kóros (ST-eleváció), a harmadikban pedig a kóros EKG-görbe mellett csak a

4. táblázat | Kardiális biomarkerek emelkedett értékei egyéb kórképekben esetenként 
szintén praenecrosist jelző MYO szintje emelkedett meg. Az EKG-görbe csak a valóban AMI-s betegek egy részében (16-ból 6 eset) és egy angina pectoris esetében volt kóros. A leginkább az AMI-ra hasonlító szívbiomarker(ezen belül hsTnI és hsTnT) emelkedéssel járó egyéb kórképeket (7 eset) szemlélteti a 4. táblázat. Egyéb betegségekben a felvételi és a 6 órán belüli hsTn-szintek között nem volt szignifikáns különbség (hsTnI: $\mathrm{z}=-0,057, \mathrm{p}>0,955)$; hsTnT: $\mathrm{z}=-0,57, \mathrm{p}>0,568)$. AMI-ban a kevés beteg (3 eset) miatt nem volt értelme elvégezni a Wilcoxon-próbát. Ezen betegeknél a hsTnértékek változását mutatja az 5. táblázat.

5. táblázat |A hsTn-értékek változása AMI-ban

\begin{tabular}{lll|ll}
\hline \multirow{2}{*}{ Betegek } & \multicolumn{2}{l|}{ hsTnI $(\mathrm{ng} / \mathrm{mL})$} & \multicolumn{2}{l}{ hsTnT $(\mathrm{ng} / \mathrm{mL})$} \\
\cline { 2 - 5 } & 1. mérés & 2. mérés & 1. mérés & 2. mérés \\
\hline 1. & 0,95 & 57,5 & 0,035 & 0,72 \\
2. & 0,46 & 34,88 & 0,028 & 0,34 \\
3. & 0,3 & 15,17 & 0,018 & 0,44 \\
\hline
\end{tabular}

\section{Megbeszélés}

Az Egészségügyi Világszervezet (WHO) 1971-ben fogalmazta meg először az AMI standardizált meghatározását. A fajlagos és reprodukálható szívnecrosis-biomarkerek megjelenésével jobban lehetett definiálni az AMI-t. 2000-ben és 2007-ben publikálták az AMI univerzális meghatározását. A szívnecrosis diagnózisának jelentős fejlődése és a myocardiumnecrosis módosított definíciója eredményezte az AMI harmadik egységes meghatározását 2012-ben. A meghatározásban központi szerepet kapott a szívbiomarkerek szintjének emelkedése és/vagy esése legalább egy, a referenciatartomány felső értékét vagy a felső érték 99-es percentilisét meghaladó értékkel. A nagy érzékenységü és fajlagosságú troponinok (hsTn) lettek a preferált biomarkerek [3]. A troponin három részből álló fehérjekomplex, aminek nélkülözhetetlen szerepe van a kalciumérzékeny molekuláris kapcsolásban a harántcsíkolt izom kontrakciójakor. A TnC alegység megköti az intracelluláris kalciumot és a TnI (gátló alegység) és TnT (tropomiozinkötő alegység) továbbítják a kalciumkötés jelét a vékony filamentumhoz. A TnI és TnT szívfajlagos izoformáját kizárólag a myocardium sejtjei expresszálják. A TnI és TnT keringésbe jutási mechanizmusa még nem teljesen ismert [4]. A troponinok mérése előtt, illetve ahol nem volt hozzáférhető meghatározásuk, a CK-t és a CKMB-t használták necrosismarkerként. A CK enzim 2 alegységből ( $M$ és B) áll, amelyek 3 különböző izoenzimet (CKBB [agy], CKMB [szív], CKMM [vázizom]) hoznak létre. 1965ben vezették be mint myocardiumkárosodást jelző biomarkert. Bár érzékenysége megfelelő, a fajlagossága nagyon alacsony. Az AMI tüneteinek megjelenése után 12 órával emelkedik meg szintje nagymértékben, ami 1-1,5 nap után tetőzik, így a korai diagnózisra nem alkalmas.
A CKMB nem teljesen szívfajlagos. A szívizom összes CK-aktivitásának csak a 15-40\%-át adja. Mivel nem eléggé érzékeny, szintén nem alkalmas az AMI 6 órán belüli felismerésére. Fokozandó a szívfajlagosságot, a CK és a CKMB együttes mérését javasolták. Ha az összes CK-n belül a CKMB aránya nagyobb, mint 6\%, akkor azt szívkárosodásnak tartották. A praenecrosismarker MYO oxigénkötő és -szállító hem fehérje, ami a vörös izmokban (váz, szív) tárolja az oxigént. Kis mérete és a sejtnedvben való elhelyezkedése lehetővé teszi korai ( 6 órán belül) koncentrációemelkedését az AMI tüneteinek megjelenése után, de nem myocardiumfajlagos marker. További praenecrosismarker a HFABP, amely a szív fó energiaforrásának számító oldhatatlan zsírsavakat szállítja a szívizomsejtekben. Tulajdonságai hasonlóak a MYO-hoz, de sokkal szívfajlagosabb. Egyes szerzők szerint a MYO/ HFABP hányados értéke jól elkülöníti egymástól a szívés a vázizom-károsodást [5]. Az AMI bekövetkezte utáni praenecrosis- és necrosis-biomarkerek koncentrációjának változását mutatja a 3. ábra. A gyulladást jelző akutfázisfehérjét, a CRP-t a májsejtek termelik. Jelenleg úgy tartják, hogy az atheroscleroticus plakk repedését, erózióját a benne fellépő gyulladás okozza. Az emelkedett CRPszint fokozott cardiovascularis kockázatot jelent. Maga a CRP is mediálja az atherothrombosist. Egy tanulmány szerint az AMI bekövetkezte után 12-24 óra között mért CRP-szint előre jelzi a szívelégtelenség és a halál előfordulását. Nagy probléma a CRP-nél, hogy egyéb gyulladásos állapotokban is emelkedik koncentrációja [2]. A fehérvérsejtekben az oxidatív stresszre válaszul termelődő lysosomalis MPO aktiválhatja a metalloproteinázokat és inaktiválhatja a plazminogénaktivátor inhibitort, így játszva szerepet az atheroscleroticus plakk repedésében. AMI után gyorsan kialakul az MPO csúcsszintje és nem korrelál a troponinok koncentrációjával vagy a neutrophilgranulocyta-számmal $[2,6]$. Kísérletünkben annak ellenére, hogy az MPO- és a (CKMB/

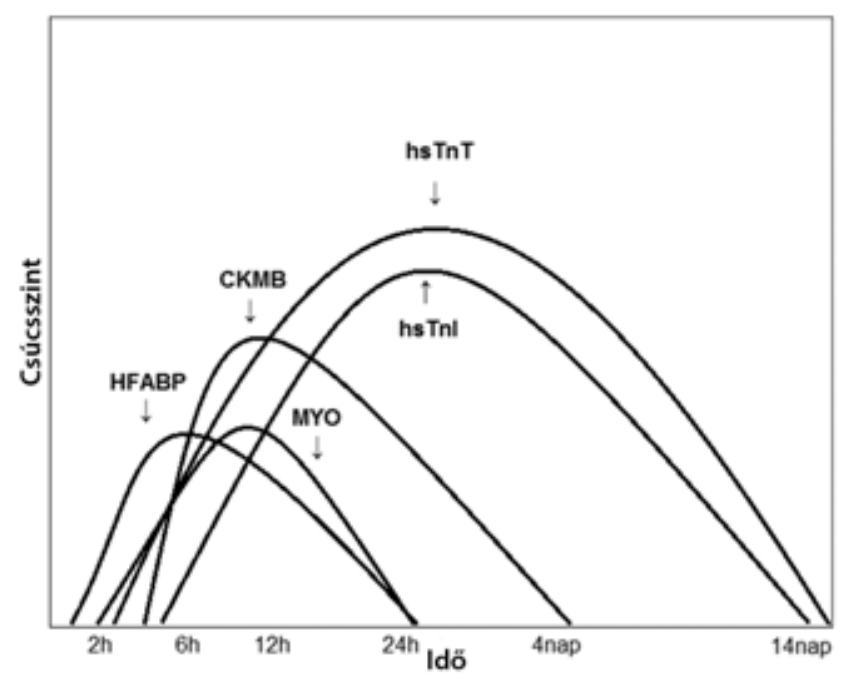

3. ábra $\quad$ A praenecrosis- és necrosismarkerek koncentrációjának változása az idő függvényében 
CK) × 100 értékek szignifikánsan különböztek szív- és nem szíveredetú betegségekben, az első esetben a diagnosztikai hatékonyság elfogadhatatlan $(0,38, \mathrm{CI}: 0,26-$ $0,49, \mathrm{p}=0,047$ ), a második esetben (lásd Eredmények részt) pedig gyenge volt. Az AMI és egyéb kórképek elkülönítése során hasonló volt a helyzet a MYO/HFABP $(0,45, \mathrm{CI}: 0,08-0,29, \mathrm{p}=0,051)$ és a CK $(0,69, \mathrm{CI}$ : $0,5-0,19, \mathrm{p}=0,009)$ esetében. Viszont a MYO, CKMB, $(\mathrm{CKMB} / \mathrm{CK}) \times 100$ esetében elfogadható a HFABP, hsTnI és hsTnT esetében pedig jó volt a diagnosztikai hatékonyság. Utóbbi 3 analit fajlagossága és/vagy érzékenysége mégsem volt megfelelő sem a kritikus, sem az optimális kritikus értékeknél. Az Eredmények fejezetben részletesen taglaltuk, hogy az AMI-n kívül mely betegségekben találtunk emelkedett hsTn-koncentrációt. Ez megfelelt a szakirodalomban már leírtaknak, kivéve, hogy subileusban és exsiccosisban is emelkedhet a hsTn koncentrációja $[7,8,9,10]$. Az emelkedés okát jelenleg csak feltételezések magyarázzák. Szívelégtelenségben a krónikusan károsodott myocardiumban sérülhetnek a kontraktilis proteinek, és kikerülhetnek a keringésbe. Krónikus veseelégtelenségben megnőhet a kardiális szabad troponinok koncentrációja, fokozódhat a kardiális troponinok vázizombeli termelődése, illetve a csökkent clearance-ük is emelheti szintjüket. Akut agysérülésben nagy mennyiségú noradrenalin szabadul fel a myocardialis interstitiumban végződő szimpatikus idegekből, ami izomsejtnecrosist okozhat. A tüdőembólia kardiogén sokkot és jobbkamra-dilatációt válthat ki. A hirtelen megnőtt oxigénszükséglet nyomásfokozódást vált ki, csökken a kamrából a vérkiáramlás és endothelialis mediátorok szabadulnak fel, amelyek jobbkamra-ischaemiát és -károsodást okoznak. Tüdőbetegségekben a pulmonalis hypertensio, a hypoxia és a hypercapnia szintén myocardiumkárosodást idézhet elő. A myocardium megnőtt oxigénszükséglete, a fokozott falfeszülés, a hypertensio, a tachycardia és myocardialis toxinok kis myocardiumsérülést okozhatnak szepszisben. A troponinok kis molsúlyú részekké törhetnek és a membrán-áteresztőképesség fokozódása miatt a keringésbe kerülhetnek. Erőteljes izommunka emelheti a szabad gyökök szintjét, ami szintén növeli a membrán-áteresztőképességet. A tachycardiák és a pitvarfibrilláció a myocardium oxigénszükségletét növelve eredményezhet emelkedett troponinszintet [11]. Tapasztalataink szerint a hsTnI koncentrációja az AMI-n kívül többféle betegségben emelkedett meg, mint a hsTnT szintje. Ennek az is lehet a magyarázata, hogy a TnT molsúlya (körülbelül 36 kDa; TnI: $24 \mathrm{kDa}$ ) nagyobb, és így nehezebben jut át a szívizomsejt sejthártyáján. Az irodalmi adatokkal ellentétben, méréseink szerint a HFABP nem volt fajlagosabb (40\%) a MYO-nál (kritikus érték: $70 \mathrm{ng} / \mathrm{ml}$, érzékenység $75 \%$, fajlagosság $49 \%$ ), sőt valamivel rosszabb volt a fajlagossága AMI-ban. A markerek közül a hsTnI és a hsTnT kombinációja segítette legjobban az AMI felismerését, amit nagymértékben fokozni lehetett az EKGgörbe ismeretével és a mellkasi fájdalom tünet meg- vagy nem létével. Azonban az AMI-s esetek 37,5\%-ában nem volt kórjelző a 4 változó felvételkor. Meune és mtsai tanulmányában 6\% volt ez az arány. Ezen esetekben nagyon alacsony volt az 1 éven belüli mortalitás, ugyanakkor az AMI előfordulása megnőtt [12]. Szánthó és mtsai nemzetközi ajánlások és saját adatok alapján javasolták, hogy nem egyértelmû esetekben 3-6 óra elteltével meg kell ismételni a hsTn-mérést: „Ha a Tn legalább kétszeresére nő, és EKG-eltérések (például ST-eleváció kialakulása), illetve a klinikai tünetek súlyosbodása ezt indokolja, az akut myocardialis infarctus valószínú, és a beteget ennek megfelelően kell ellátni." Esetükben és esetünkben (5. táblázat) is, nagyságrendekkel több volt a hsTn-ek értéke a 2. méréskor [13]. Ugyanakkor több mint kétszeres hsTn-koncentráció-emelkedés más betegségben (például: TIA) is előfordulhat. Egy munkacsoport az először mért hsTnT-értékek szerint 4 kockázati csoportot állapított meg: átlagos kockázat: < 0,030 ng/ $\mathrm{mL}$; kissé emelkedett kockázat: 0,030-0,066 ng/mL; közepes kockázat: 0,067-0,099 ng/mL; magas kockázat: $>0,1 \mathrm{ng} / \mathrm{mL}$. Kísérletükben az átlagos kockázatú csoportban $17 \%$, a kissé emelkedettben $29 \%$, a közepesben $64 \%$, a magasban $85 \%$ volt az AMI elöfordulása [14]. Tanulmányunkban $6 \%$, nem volt ilyen besorolású betegünk, $50 \%$ és $86 \%$ volt ez a mutató. Méréseink alapján bár a HFABP nem fajlagosabb, mint a MYO, viszont jóval érzékenyebbnek bizonyult nála AMI-ban. Ebből adódik magasabb diagnosztikus hatékonysága. Ezért másokkal egyetértve: a MYO helyett kellene mérni, mint korai markert [15].

A hsTnI sokkal érzékenyebbnek, de kevésbé fajlagosnak bizonyult, mint a hsTnT AMI-ban. Együttes mérésük előnyösebb lenne, de nagyon költséges. Amíg nem fedeznek fel megfelelő érzékenységű és fóleg fajlagosságú szívbiomarkert, addig nincs jobb módszer AMI gyanúja esetén, mint az EKG és biomarker-monitorozás. Ez viszont idővesztést okoz, ami késlelteti a terápiás beavatkozást. A szívbiomarker-kutatások több irányba is folynak. Prognosztikai, plakk, korai és további szívizomsejtnecrosis-biomarkereket keresnek. A prognosztikai markerek (oldható OX40 ligand, MPO, rezisztin, oldható ST2 fehérje) egy esetleg későbbi időpontban bekövetkező AMI valószínúségét jelzik $[6,16,17,18]$. A plakkmarkerek (visfatin, galectin-3, oldható lectinszerű oxidált LDL-receptor-1, lipoproteinasszociált foszfolipáz-A2, leukotrién-B4, extracelluláris mátrixmetalloproteináz, triptáz, oldható LRll fehérje, oldható amyloid prekurzor fehérje 770, apelin, chitotriosidas, tenascin-C) az instabilitást, a sérülés bekövetkeztét, mértékét mutatják, így utalva az AMI lehetőségére [19, 20, 21, 22, 23, 24, $25,26,27,28,29,30]$. Ígéretes korai markernek tünik az ischaemiamodifikált albumin, a hősokkfehérje-27, a katepszin-K, a Clq-kötő adiponectin, a sejtmentes keringő DNS, a májsejt-növekedési faktor, a glikogén foszforiláz BB izoenzim és a növekedést elkülönítő faktor 15 [31, 32, 33, 34, 35, 36, 37, 38, 39]. A tanulmányok szerint az újonnan vizsgált necrosismarkerek (szívmio- 
zinkötő fehérje C és sarcoplasmás reticulum $\mathrm{Ca}^{2+}$-ATPáz) sokkal szívfajlagosabbak, mint a jelenleg használatosak $[40,41,42]$. A biomarkerek mellett olyan új képalkotó eljárások is segítik az AMI diagnózisát, mint a szív mágneses rezonanciás képalkotás (cMRI) és az optikai koherens tomográfia (OCT) $[43,44]$. Ha a szívbiomarkercsoportokban (plakk, prognosztikai, korai, necrosis) az újabban vizsgált anyagok közül valamelyik használhatósága széles körű megerősítést nyer, akkor akár teljesen átalakulhat az AMI laboratóriumi diagnosztikai eszköztára és módosulhat a definíciója is.

Anyagi támogatás: A közlemény megírása anyagi támogatásban nem részesült.

Szerzői munkamegosztás: K. F.: A kézirat megszövegezése. K. I.: A TnT mérése. V. M.: A kézirat lektorálása. S. E.: A mieloperoxidáz mérése. B. Gy.: A fő tünetek és a diagnózisok kiválasztása. A cikk végleges változatát valamennyi szerző elolvasta és jóváhagyta.

Érdekeltségek: A szerzóknek nincsenek érdekeltségeik.

\section{Irodalom}

[1] Mortalities according to most common causes of death (1990-). [Halálozások a gyakoribb halálokok szerint (1990-).] https:// www.ksh.hu/docs/hun/xstadat/xstadat_eves/i_wnh001.html [Hungarian]

[2] Chan, D., Ng, L. L.: Biomarkers in acute myocardial infarction. BMC Med., 2010, 8(34), 1-11.

[3] Jneid, H., Alam, M., Virani, S. S., et al.: Redefining myocardia infarction: what is new in the ESC/ACCF/AHA/WHF third universal definition of myocardial infarction? Methodist Debakey Cardiovasc. J., 2013, 9(3), 169-172.

[4] Christenson, E., Christenson, R. H.: The role of cardiac biomarkers in the diagnosis and management of patients presenting with suspected acute coronary syndrome. Ann. Lab. Med., 2013, 33(5), 309-318.

[5] Al-Hadi, H. A., Fox, K. A.: Cardiac markers in the early diagnosis and management of patients with acute coronary syndrome. Sultan Qaboos Univ. Med. J., 2009, 9(3), 231-246.

[6] Kaya, M. G., Yalcin, R., Okyay, K., et al.: Potential role of plasma myeloperoxidase level in predicting long-term outcome of acute myocardial infarction. Tex. Heart Inst. J., 2012, 39(4), 500506.

[7] Lindner, G., Pfortmueller, C. A., Braun, C. T., et al.: Non-acute myocardial infarction-related causes of elevated high-sensitive troponin $\mathrm{T}$ in the emergency room: a cross-sectional analysis. Intern. Emerg. Med., 2014, 9(3), 335-339.

[8] Agewall, S., Giannitsis, E., Jernberg, T., et al.: Troponin elevation in coronary vs. non-coronary disease. Eur. Heart J., 2011, 32(4), 404-411.

[9] Babić, Z., Bogdanović, Z., Dorosulić, Z., et al.: Quantitative analysis of troponin I serum values in patients with acute cholecystitis. Coll. Antropol., 2012, 36(1), 145-150.

[10] Aundhakar, S. C., Mahajan, S. K., Agarwal, A. O., et al.: Acute pancreatitis associated with elevated troponin levels: whether to thrombolyse or not? Ann. Med. Health Sci. Res., 2013, 3(5 Suppl. 1), S50-S52.

[11] Tanindi, A., Cemri, M.: Troponin elevation in conditions other than acute coronary syndromes. Vasc. Health Risk Manag. 2011, 7, 597-603
[12] Meune, C., Balmelli, C., Twerenbold, R., et al.: Patients with acute coronary syndrome and normal high-sensitivity troponin. Am. J. Med., 2011, 124(12), 1151-1157.

[13] Szánthó, E., Szabó, Z., Varga, J., et al.: Interpretation of high sensitive troponin assays: acute or chronic myocardial damage? [Nagy érzékenységú troponintesztek értékelése: akut vagy krónikus szívizom-károsodás?] Orv. Hetil., 2011, 152(38), 15281534. [Hungarian]

[14] Zarich, S. W., Bradley, K., Mayall, I. D. et al.: Minor elevations in troponin $T$ values enhance risk assessment in emergency department patients with suspected myocardial ischemia: analysis of novel troponin T cut-off values. Clin. Chim. Acta, 2004, 343(12), 223-229.

[15] Dekker, M. S., Mosterd, A., van 't Hof, A. W., et al.: Novel biochemical markers in suspected acute coronary syndrome: systematic review and critical appraisal. Heart, 2010, 96(13), 10011010.

[16] Yan, J., Gong, J., Chen, G., et al.: Evaluation of serum soluble OX40 ligand as a prognostic indicator in acute coronary syndrome patients. Clin. Chim. Acta, 2010, 411(21-22), 16621665.

[17] Li, L., Han, J. L., Mao, J. M., et al.: Association between serum resistin level and cardiovascular events in postmenopausal women with acute coronary syndrome undergoing percutaneous coronary intervention. Chin. Med. J. (Engl.), 2013, 126(6), 1058-1062.

[18] Zhang, K., Zhang, X. C., Mi, Ү. H., et al.: Predicting value of serum soluble ST2 and interleukin-33 for risk stratification and prognosis in patients with acute myocardial infarction. Chin. Med. J. (Engl.), 2013, 126(19), 3628-3631.

[19] Lu, L. F., Wang, C. P., Yu, T. H., et al.: Interpretation of elevated plasma visfatin concentrations in patients with ST-elevation myocardial infarction. Cytokine, 2012, 57(1), 74-80.

[20] Falcone, C., Lucibello, S., Mazzucchelli, I., et al.: Galectin-3 plasma levels and coronary artery disease: a new possible biomarker of acute coronary syndrome. Int. J. Immunopathol. Pharmacol., $2011,24(4), 905-913$.

[21] Kobayashi, N., Hata, N., Kume, N., et al.: Soluble lectin-like oxidized low-density lipoprotein receptor-1 as an early biomarker for ST elevation myocardial infarction: time-dependent comparison with other biomarkers. Circ. J., 2011, 75(6), 14331439.

[22] Pirillo, A., Catapano, A. L.: Soluble lectin-like oxidized low density lipoprotein receptor- 1 as a biochemical marker for atherosclerosis-related diseases. Dis. Markers, 2013, 35(5), 413-418.

[23] Chung, H., Kwon, H. M., Kim, J. Ү., et al.: Lipoprotein-associated phospholipase $\mathrm{A}_{2}$ is related to plaque stability and is a potential biomarker for acute coronary syndrome. Yonsei Med. J., 2014, 55(6), 1507-1515.

[24] Xu, S., Tang, L., Mi, Y., et al.: Clinical significance of leukotriene b4 and extracellular matrix metalloproteinase inducer in acute coronary syndrome. Clin. Invest. Med., 2013, 36(6), E282E289.

[25] Pastorello, E. A., Morici, N., Farioli, L., et al.: Serum tryptase: a new biomarker in patients with acute coronary syndrome? Int. Arch. Allergy Immunol., 2014, 164(2), 97-105.

[26] Ogita, M., Miyauchi, K., Dohi, T., et al.: Increased circulating soluble LR11 in patients with acute coronary syndrome. Clin. Chim. Acta, 2013, 415, 191-194.

[27] Kitazume, S., Yoshibisa, A., Yamaki, T., et al.: Soluble amyloid precursor protein 770 is released from inflamed endothelial cells and activated platelets: a novel biomarker for acute coronary syndrome. J. Biol. Chem., 2012, 287(48), 40817-40825.

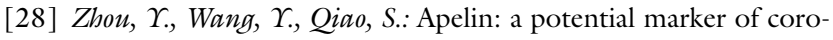
nary artery stenosis and atherosclerotic plaque stability in ACS patients. Int. Heart J., 2014, 55(3), 204-212. 
[29] Yildiz, B. S., Barutcuoglu, B., Alibanoglu, Y. I., et al.: Serum chitotriosidase activity in acute coronary syndrome. J. Atheroscler. Thromb., 2013, 20(2), 134-141.

[30] Sakamoto, N., Hoshino, Y., Misaka, T., et al.: Serum tenascin-C level is associated with coronary plaque rupture in patients with acute coronary syndrome. Heart Vessels, 2014, 29(2), 165-170.

[31] Dawie, J., Chawla, R., Worku, Y., et al.: Diagnosis of ischemic heart disease using CK-MB, troponin-I and ischemia modified albumin. Ethiop. Med. J., 2011, 49(1), 25-33.

[32] Sygitowicz, G., Janas, J., Biatek, S., et al.: Ischaemia modified albumin in patients with acute coronary syndrome and negative cardiac troponin I. Scand. J. Clin. Lab. Invest., 2013, 73(2), $130-134$.

[33] Heidari-Bakavoli, A. R., Sahebkar, A., Mobara, N., et al.: Changes in plasma level of heat shock protein 27 after acute coronary syndrome. Angiology, 2012, 63(1), 12-16.

[34] Cheng, X. W., Kikuchi, R., Ishii, H., et al.: Circulating cathepsin $\mathrm{K}$ as a potential novel biomarker of coronary artery disease. Atherosclerosis, 2013, 228(1), 211-216.

[35] Kishida, K., Nakagawa, Y., Kobayashi, H., et al.: High serum $\mathrm{Clq}$-binding adiponectin levels in male patients with acute coronary syndrome. Cardiovasc. Diabetol., 2014, 13, 9.

[36] Cui, M., Fan, M., Jing, R., et al.: Cell-free circulating DNA: a new biomarker for the acute coronary syndrome. Cardiology, $2013,124(2), 76-84$.

[37] Konopka, A., Janas, J., Piotrowski, W., et al.: Hepatocyte growth factor - a new marker for prognosis in acute coronary syndrome. Growth Factors, 2010, 28(2), 75-81.

[38] Bozkurt, S., Kaya, E. B., Okutucu, S., et al.: The diagnostic and prognostic value of first hour glycogen phosphorylase isoenzyme
BB level in acute coronary syndrome. Cardiol. J., 2011, 18(5), 496-502.

[39] Fan, L. Y., Jin, Z. G., Zong, M., et al.: Growth differentiation factor 15 , ischemia modified albumin and pregnancy-associated plasma protein A in patients with coronary artery disease. Clin. Lab., 2014, 60(6), 973-982.

[40] Kuster, D. W., Cardenas-Ospina, A., Miller, L., et al.: Release kinetics of circulating cardiac myosin binding protein-C following cardiac injury. Am. J. Physiol. Heart Circ. Physiol., 2014, 306(4), H547-H556.

[41] Govindan, S., Kuster, D. W., Lin, B., et al.: Increase in cardiac myosin binding protein- $\mathrm{C}$ plasma levels is a sensitive and cardiacspecific biomarker of myocardial infarction. Am. J. Cardiovasc. Dis., 2013, 3(2), 60-70.

[42] Tchobanu, L. M., Syrbu, S. I., Popovitch, I. M., et al.: The immuneenzyme technique of detection of Ca2 + ATPase of sarcoplasmic reticulum - a new biologic marker of acute cardiac infarction. Klin. Lab. Diagn., 2013, 5, 39-42.

[43] Akerem Khan, S., Williamson, E. E., Foley, T. A., et al.: Cardiac MRI of acute coronary syndrome. Future Cardiol., 2013, 9(3), 351-370.

[44] Kubo, T., Tanaka, A., Ino, ., et al.: Assessment of coronary atherosclerosis using optical coherence tomography. J. Atheroscler. Thromb., 2014, 21(9), 895-903.

(Kovács Ferenc dr., Nagykanizsa, Szekeres u. 2-8., 8800 e-mail: drkovacs@nkkorhaz.hu)

\section{Az Orvosi Hetilap 2015, 156, 752. oldalán (18. szám) megjelent OH-Kvízre hat helyes megfejtés érkezett.}

A beküldők: Dr. Bíró László (Budapest), Dr. Janik Leonárd (Budapest), Dr. Kónya Csaba (Budapest), Dr. Mészáros Dóra (Budapest), Dr. Pallos Ágnes (Budapest) és Dr. Somogyi Erzsébet (Miskolc).

\section{A nyerteseknek szívből gratulálunk.}

A nyereményüket - egy, az Akadémiai Kiadó webáruházában kedvezményes vásárlásra jogosító kupont - e-mailen küldjük el. 